\title{
The Effect of Types of Nasal Septum Deviation on the Eustachian Tube Function
}

\author{
(1) Remzi DOĞAN
}

Bezmialem Vakıf University Faculty of Medicine, Department of Otorhinolaryngology, İstanbul, Turkey

\begin{abstract}
Objective: Nasal septum deviations are divided into six different subtypes in the literature. Because obstruction and nasal airflows in the nasal passages that these types form are different, their effects on the eustachian tube can be different. The effect of different nasal septum deviations on eustachian tube function was investigated in our study.

Methods: A total of 80 patients with six different septum types and 15 healthy volunteers were included in the study. We tested eustachian tube function with P1, P2, and P3. P1 is the tympanometric measurement while resting. P2 is the tympanometric measurement after the Toynbee maneuver. P3 is the tympanometric testing after the Valsalva maneuver. To evaluate the functionality of the eustachian tube, we used the P1-P2 $>10 \mathrm{daPa}$ or $\mathrm{P}_{\max }-\mathrm{P}_{\min }>15 \mathrm{daPa}$ criteria. Measurements were performed before and 6 months after surgery.

Results: Before surgery, there was no difference between types 1,2,3, and 5 and healthy volunteers in terms of eustachian tube dysfunction. Before surgery, type 4 and 6 had significant eustachian tube dysfunction compared with healthy volunteers. Type 4 and 6 showed significant improvement in the eustachian tube functions at $6^{\text {th }}$ month after operation.

Conclusion: According to the results of our study, applying septoplasty only to patients with type 4 and 6 nasal septum deviations before middle ear surgery would reduce unnecessary cost and increase the success of middle ear surgeries by preventing morbidities.
\end{abstract}

Keywords: Nasal septum type, eustachian tube, septoplasty, middle ear

\section{Introduction}

The eustachian tube (ET) is a small passage between the middle ear and the nasopharynx and its main function is to provide ventilation of the middle ear (1). ET equalizes the pressure in the middle ear with the atmospheric pressure. Nasal pathologies (anatomic, functional) may affect the middle ear ventilation by acting on the ET. The effects of nasal obstruction on the pathophysiology of middle ear diseases and the success rates of the surgeries (tympanoplasty, miringoplasty) performed in this region are debated (2).

The importance of ET for the middle ear is not fully understood, although it is clearly demonstrated that this structure is affected by nasal pathologies. However, whether before all middle ear surgeries, all septal deviations in the nose should be corrected is still controversial. In the literature, there are studies claiming that surgical operation is needed to provide healthy functions of the ET (ETF) and for the successful middle ear surgeries (3-5), as well as there are studies claiming that surgical operation is unnecessary $(2,6,7)$. Because we do not have a common practice, the choice is mostly left to the physician. This choice sometimes leads to unsuccessful tympanoplasty with incomplete treatment and sometimes can lead to increase in cost and additional morbidities with excessive treatment.

Nasal septum deviation (NSD) is divided into several sub-types and different obstructions can occur in nasal passage depending 
on the severity of the deviation. Our goal in our study is to find out what kind of nasal septal deviation affects the ETF. Thus, we suggest that prior to middle ear surgery, incomplete treatment or over-treatment can be avoided.

\section{Methods}

Our study was started after approved by the Ethics Committee of Clinical Research of the Bezmialem Vakıf University Faculty of Medicine with the number 71306642-050.01.04. Eighty patients who were admitted to the otorhinolaryngology out patient clinic with nasal congestion were included in the study. Fifteen healthy volunteers with normal examination were referred as the control group. Patients and healthy controls were informed about the study and informed and oral consents were taken from them.

The patient group was divided into six groups according to the Baumann and Baumann's (8) classification of nasal septum, one of the most frequently used classifications in the literature (Figure 1):

Group 1 ( $\mathrm{n}=30$ ears, 15 patients): NSD type 1,

Group 2 ( $\mathrm{n}=28$ ears, 14 patients): NSD type 2,

Group 3 ( $\mathrm{n}=28$ ears, 14 patients): NSD type 3,

Group 4 (n=24 ears, 12 patients): NSD type 4,

Group 5 ( $\mathrm{n}=26$ ears, 13 patients): NSD type 5 ,

Group 6 (n=24 ears, 12 patients): NSD type 6,

Group 7 ( $\mathrm{n}=30$ ears, 15 patients): Healthy volunteers with no deviation of nasal septum.

Full otolaryngologic examination was performed in the study and control groups. Patients without intact tympanic membrane, with ear history (radical and modified radical mastoidectomy, chronic otitis media, adhesive otitis media), with upper respiratory tract obstructive pathologies (adenoid vegetation, nasal polyposis, nasal synechia, and upper respiratory tract infections) were excluded from the study.

Tympanometric measurements and automated ETF tests (ETFT) were performed with Impedance Audiometry AC40. In the present study, an automated Toynbee test was used to evaluate the ETF in patients with nasal septal deviation and healthy volunteers in the control group.

In these patients, type A tympanogram peaks are between -100 and $+100 \mathrm{daPa}$ and this determines normal middle ear function

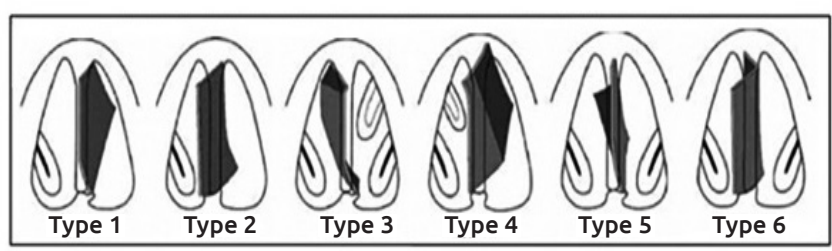

Figure 1. Six types of nasal septum deviation
(1 daPa=1.02 $\mathrm{mm} \mathrm{H}_{2} \mathrm{O}$ ) (9). P1 is the stable timpanometric measure. P2 is the Toynbee test which is the result of swallowing when the mouth and nose of patients are closed. The P3 is the Valsalva maneuver which occurs when the mouth and nose of the patients are closed. Peak pressure values were recorded as $\mathrm{P} 1, \mathrm{P} 2$ and $\mathrm{P} 3$ and the maximum and the minimum pressure values were recorded as maximum pressure difference $=\mathrm{P}_{\max }-\mathrm{P}_{\min }$. The criteria $\mathrm{P} 1-\mathrm{P} 2>10$ or $\mathrm{P}_{\max }-\mathrm{P}_{\min }>15$ were used to evaluate ET as functional. In these criteria, $\mathrm{P} 1$ is the peak point of classic timpanometry, $\mathrm{P} 2$ is the peak point of the Toynbee test and $\mathrm{P} 3$ is the peak point of the Valsalva test (9).

\section{Statistical Analysis}

Statistical analyses were performed with the Statistical Package for the Social Sciences 16.0 for Windows ile (SPSS Inc.; Chicago, IL, USA). Numeric variables were expressed as mean and standard deviation. The one way ANOVA test was used in comparison between groups. Paired t-test was used for pre- and post-operative comparisons in each group. $\mathrm{P}<0.05$ was considered significant.

\section{Results}

There were no differences between groups in terms of age and gender ( $p>0.05)$ (Table 1). The mean values of $\mathrm{P}_{\max }-\mathrm{P}_{\min }$ in ETFT performed to the right and left ears of the patients and controls in the groups were calculated. $\mathrm{P}_{\max }-\mathrm{P}_{\min }>15 \mathrm{daPa}$ was considered as functional ET. There was no difference between groups 1, 2, 4, 5 and 7 in terms of preop $\mathrm{P}_{\text {max }}-\mathrm{P}_{\min }$ mean and $\mathrm{P}_{\max }-\mathrm{P}_{\min }$ mean (Table 2). The mean $P_{\max }-P_{\text {min }}$ values in group 4 and 6 were less than 15 $\mathrm{daPa}$ and were $11.41 \pm 6.22$ and $10.62 \pm 5.37$, respectively. These values were statistically significantly lower than the mean $\mathrm{P}_{\max }-$ $\mathrm{P}_{\min }$ value in healthy controls which was $42.63 \pm 15.19(\mathrm{p}=0.001$ and $\mathrm{p}=.001$, respectively) (Table 2 ).

Table 1. Demographic features of the groups

\begin{tabular}{|c|c|c|c|c|}
\hline Groups & $\begin{array}{l}\text { Gender } \\
\text { Male/ } \\
\text { Female }\end{array}$ & $\begin{array}{l}\text { Statistics } \\
\text { p values }\end{array}$ & $\begin{array}{l}\text { Age } \\
\text { Mean } \pm \text { SD }\end{array}$ & $\begin{array}{l}\text { Statistics } \\
\text { p values }\end{array}$ \\
\hline $\begin{array}{l}\text { Group } 1(n=25) \text { : } \\
\text { NSD type } 1\end{array}$ & $13 / 12$ & - & $27.34 \pm 4.82$ & - \\
\hline $\begin{array}{l}\text { Group } 2 \text { ( } n=23 \text { ): } \\
\text { NSD type } 2\end{array}$ & $11 / 12$ & - & $24.09 \pm 7.38$ & - \\
\hline $\begin{array}{l}\text { Group } 3(n=21) \text { : } \\
\text { NSD type } 3\end{array}$ & $12 / 9$ & - & $31.55 \pm 6.19$ & - \\
\hline $\begin{array}{l}\text { Group } 4(n=20) \text { : } \\
\text { NSD type } 4\end{array}$ & $13 / 7$ & $p>0.05$ & $29.37 \pm 5.03$ & $p>0.05$ \\
\hline $\begin{array}{l}\text { Group } 5 \text { ( } n=23) \text { : } \\
\text { NSD type } 5\end{array}$ & $14 / 9$ & - & $33.76 \pm 9.16$ & - \\
\hline $\begin{array}{l}\text { Group } 6(n=19) \text { : } \\
\text { NSD type } 6\end{array}$ & $11 / 8$ & - & $26.01 \pm 8.59$ & - \\
\hline $\begin{array}{l}\text { Group } 7(n=25) \text { : } \\
\text { Control }\end{array}$ & $15 / 10$ & - & $30.47 \pm 6.23$ & - \\
\hline Total $(n=156)$ & $89 / 67$ & - & $28.94 \pm 6.77$ & - \\
\hline
\end{tabular}


Table 2. Preop eustachian tube function tests in the groups

\begin{tabular}{|c|c|c|}
\hline Groups & $\begin{array}{l}P_{\max }-P_{\min }(\mathrm{daPa}) \\
\text { Mean } \pm \mathrm{SD}\end{array}$ & $\begin{array}{l}\text { Statistics } \\
\text { p values }\end{array}$ \\
\hline $\begin{array}{l}\text { Group } 1 \text { ( } n=25) \text { : NSD } \\
\text { type } 1\end{array}$ & $35.35 \pm 9.48$ & $\begin{array}{l}\text { Group } 1 \text { vs group } 7: \\
p=0.196\end{array}$ \\
\hline $\begin{array}{l}\text { Group } 2 \text { ( } n=23 \text { ): NSD } \\
\text { type } 2\end{array}$ & $22.47 \pm 7.51$ & $\begin{array}{l}\text { Group } 2 \text { vs group } 7: \\
p=0.094\end{array}$ \\
\hline $\begin{array}{l}\text { Group } 3 \text { ( } n=21) \text { : NSD } \\
\text { type } 3\end{array}$ & $30.02 \pm 11.06$ & $\begin{array}{l}\text { Group } 3 \text { vs group } 7: \\
p=0.239\end{array}$ \\
\hline $\begin{array}{l}\text { Group } 4(n=20) \text { : NSD } \\
\text { type } 4\end{array}$ & $11.41 \pm 6.22$ & $\begin{array}{l}\text { Group } 4 \text { vs group 7: } \\
p=0.001\end{array}$ \\
\hline $\begin{array}{l}\text { Group } 5(n=23) \text { : NSD } \\
\text { type } 5\end{array}$ & $39.84 \pm 12.54$ & $\begin{array}{l}\text { Group } 5 \text { vs group } 7: \\
p=0.275\end{array}$ \\
\hline $\begin{array}{l}\text { Group } 6 \text { ( } n=19) \text { : NSD } \\
\text { type } 6\end{array}$ & $10.62 \pm 5.37$ & $\begin{array}{l}\text { Group } 6 \text { vs group 7: } \\
p=0.001\end{array}$ \\
\hline $\begin{array}{l}\text { Group } 7(n=25) \text { : } \\
\text { Control }\end{array}$ & $42.63 \pm 15.19$ & - \\
\hline Total $(n=156)$ & - & - \\
\hline
\end{tabular}

\begin{tabular}{|c|c|c|c|}
\hline Groups & $\begin{array}{l}P_{\text {max }}-P_{\text {min }} \\
(\mathrm{daPa}) \\
\text { Mean } \pm \text { SD }\end{array}$ & $\begin{array}{l}P_{\max }-P_{\text {min }} \\
(\mathrm{daPa}) \\
\text { Mean } \pm \mathrm{SD}\end{array}$ & $\begin{array}{l}\text { Statistics } \\
\text { p values }\end{array}$ \\
\hline $\begin{array}{l}\text { Group } 1(n=25) \text { : } \\
\text { NSD type } 1\end{array}$ & $35.35 \pm 9.48$ & $41.01 \pm 10.37$ & $p=0.354$ \\
\hline $\begin{array}{l}\text { Group } 2(n=23) \text { : } \\
\text { NSD type } 2\end{array}$ & $22.47 \pm 7.51$ & $31.25 \pm 11.66$ & $p=0.072$ \\
\hline $\begin{array}{l}\text { Group } 3(n=21) \text { : } \\
\text { NSD type } 3\end{array}$ & $30.02 \pm 11.06$ & $38.17 \pm 13.94$ & $p=0.238$ \\
\hline $\begin{array}{l}\text { Group } 4(n=20) \text { : } \\
\text { NSD type } 4\end{array}$ & $11.41 \pm 6.22$ & $35.72 \pm 10.79$ & $p=0.001$ \\
\hline $\begin{array}{l}\text { Group } 5(n=23) \text { : } \\
\text { NSD type } 5\end{array}$ & $39.84 \pm 12.54$ & $42.96 \pm 14.01$ & $p=0.305$ \\
\hline $\begin{array}{l}\text { Group } 6(n=19) \text { : } \\
\text { NSD type } 6\end{array}$ & $10.62 \pm 5.37$ & $37.13 \pm 12.88$ & $p=0.001$ \\
\hline Total $(n=156)$ & - & - & - \\
\hline
\end{tabular}

There were no differences between the $\mathrm{P}_{\max }-\mathrm{P}_{\min }$ mean in the postoperative $6^{\text {th }}$ month and preoperative period in groups 1 , 2,3 and 5 (Table 3). The $\mathrm{P}_{\max }-\mathrm{P}_{\min }$ means in the postoperative $6^{\text {th }}$ month in group 4 and $6(35.72 \pm 10.79$ and $37.13 \pm 12.88$, respectively) were statistically significantly higher than the $\mathrm{P}_{\max }-\mathrm{P}_{\min }$ means in the preoperative period $(11.41 \pm 6.22$ and $10.62 \pm 5.37$, respectively) ( $\mathrm{p}=0.001$ and $\mathrm{p}=.001$, respectively) (Table 3).

According to the literature, P1-P2 >10 was considered as functional ET. The ETFT was positive in 27 ears and negative in 3 ears in group 7 . The positive/negative ratio was 26/4 in group

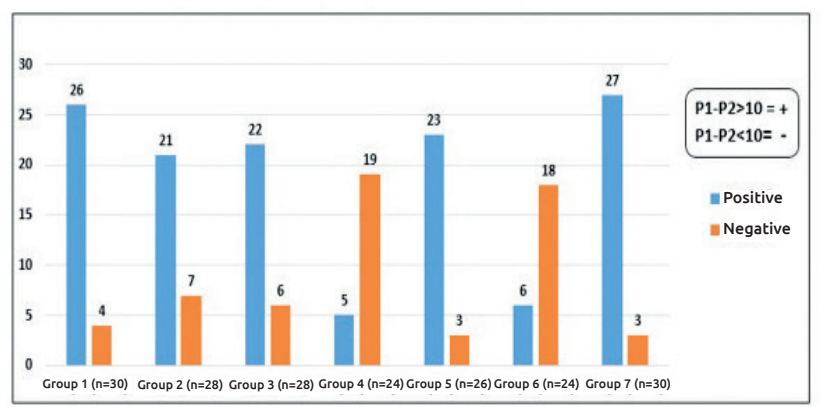

Figure 2. Eustachian tube functions of groups before operation

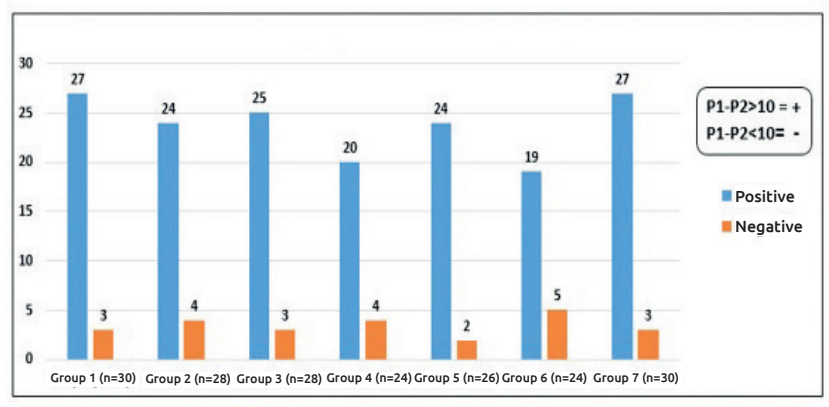

Figure 3. Eustachian tube functions of groups after operation

1 and was similar to group $7(\mathrm{p}=0.248)$ (Figure 2). The positive/ negative ratio was $21 / 7$ in group 2 and was similar to group 7 $(\mathrm{p}=0.085)$ (Figure 2$)$. The positive/negative ratio was $22 / 6$ in group 3 and was similar to group $7(\mathrm{p}=0.168)$ (Figure 2$)$. The positive/negative ratio was $5 / 19$ in group 4 and was statistically significantly lower than group $7(p=0.021)$ (Figure 2$)$. The positive/negative ratio was $23 / 3$ in group 5 and was similar to group 7 ( $p=0.291)$ (Figure 2$)$. The positive/negative ratio was $6 / 18$ in group 6 and was statistically significantly lower than group $7(\mathrm{p}=0.011)$ (Figure 2$)$.

The positive/negative status of ETFT in the postoperative 6 months were summarized in Figure 3. In groups 1, 2, 3 and 5, positive/negative ratios increased (27/3, 24/4, 25/3 and 24/2, respectively), however as preop ratios, they were not different from the ratios of group $7(\mathrm{p}=0.422, \mathrm{p}=0.119, \mathrm{p}=0.259$ and $\mathrm{p}=.358$, respectively) (Figure 3 ). The positive/negative ratio was $20 / 4$ in group 4 and there was no difference between group 4 and 7 ( $\mathrm{p}=0.163)$ (Table 3). The positive/negative ratio was 19/5 in group 6 and there was no difference between group 4 and 7 $(\mathrm{p}=0.094)$ (Table 3).

\section{Discussion}

We found ET dysfunction (ETD) in type 4 and 6 NSDs which significantly improved in the postoperative $6^{\text {th }}$ month. There was no significant ETD in types 1, 2, 3 and 5 in the preoperative period. We believe that the types of septum deviation that can affect the surgical success in patients undergoing middle ear 
surgery are type 4 and 6 . In type 1, 2, 3 and 5 deviations, surgery was considered to have no significant effect on ETF. Therefore, we think that operating patients with these types of nasal deviation who will undergo middle ear surgery is unnecessary.

There are many parameters that affect the success of surgical operations of the middle ear. One of the most important of these is that the ET is functional. A non-functional ET causes both middle ear diseases and failure of surgical operations. Schilder et al. (10) defined three subtypes of ETD. These are; dilator ETD, pressure-induced ETD and abnormal patent ETD. Among these, the most common type is the dilator type. The dilator ETD is composed of mucosal inflammation and edema caused by many reasons (upper respiratory tract infection, allergic rhinitis, sinusitis, reflux etc.) (11). It can be concluded that nasal factors have negative effect on middle ear diseases via ET.

It was shown that inflammatory, obstructive and infective pathologies in the nasal and paranasal sinuses could cause ETD (3-6). NSD is the most common of the major anatomical problems in the nose. The NSD may present with different clinical symptoms depending on the type, localization and additional pathologies of the anatomic structures. These symptoms may include nasal obstruction, nasal discharge, facial pain and headache, epistaxis, smell disorders, etc. and many patients may be asymptomatic.

Although there are many studies on the relationship between NSD and ETF, there are still no definitive data about the extent of this relationship. Although it is known that nasal pathologies affect ETF, there is limited information about how NSD affects ETF or whether it affects it. The best known of this information is that NSD affects ETF by affecting the air flow parameters (12). In addition, it is known that infection/inflammation in the nasopharyngeal region due to the conditions formed by NSD, affects ETF $(13,14)$. It is not clear how much ETF is affected in patients with NSD despite these mechanisms are known.

According to the long-known classical data; septoplasty must be performed prior to middle ear surgery $(3,5,6)$. In the studies performed, ETF has been shown to improve after septoplasty $(5,10)$. Low and Willatt $(5)$ concluded that the ipsilateral middle ear pressure in the obstructed nasal passage was negatively correlated with the asymmetry of the openings in the two nasal passages. Deron et al. (15) found that the pressure on the deviated side was higher than on the non-deviated side. Recent studies show that ETF may not be affected by NSD. Akyıldız et al. (2) showed that NSD decreased ETF but not at a level that would affect tympanoplasty results. They concluded that performing septoplasty before tympanoplasty is not necessary (2). Also, Tan et al. (16) did not recommend performing septoplasty before tympanoplasty and they indicated that septoplasty does not have effect on tympanoplasty results. However, in none of these studies, types of NSD were specified. In fact, the type and localization of NSD and additional pathologies affect the severity of the nasal obstruction and can change the air flow in the nasal passage. In our study, significantly more impairment in ETF was found in group 4 and 6 than in healthy volunteers without
NSD. In the postoperative $6^{\text {th }}$ month, there was no difference between group 4 and 6 and healthy volunteers without NSD in terms of ETF. There was no difference between NSD type 1, 2, 3 and 5 and healthy volunteers in terms of preoperative ETF and ETF. Eren et al. (17) investigated the satisfaction of the patients after the operation and the success of the operation in different types of NSD. In conclusion, it was found that patients with NSD type 2, 4 and 6 benefited more from the operation and that patient satisfaction was better (17). According to these results, all septum deviations are not required to be operated prior to middle ear surgery. Thus, increase in cost and morbidity will be avoided. We believe that septoplasty may increase the success of middle ear surgery for those with NSD type 4 and 6 .

In the study of Maier and Krebs (6), it was reported that ETF was influenced by septal deviation and conchal hypertrophy. However, it was concluded that determining surgery after evaluating the ETF would be appropriate, rather than performing septoplasty for all septum deviations (6). In that study, septoplasty was recommended in severe nasal pathologies (6). According to our results, septoplasty should be performed in patients with severe septal deviation (type 4 and 6). In the study of Maier and Krebs (6), ETF was shown to have not improved in the early postoperative period despite surgery. In our study, postop evaluation was performed in the sixth month. We believe that we have achieved safe results with proper timing.

Harju et al. (18) showed that patients with inferior nasal concha were more associated with ETD compared with healthy controls. In our study, both severe deviation and conchal pathologies were present with type 4 and 6 . In type 4 , inferior conchal hypertrophy and middle concha bullosa were present whereas in type 6, bilateral inferior conchal hypertrophy were present in the non-deviated side. These additional pathologies accompanying type 4 and 6 in our study also increased ETD and our findings were in line with the literature.

\section{Study Limitations}

The strengths of our study are that for the first time in the literature ETD was examined with septum classification, the number of patients was sufficient and prospective measurements (postop sixth month) were performed. The limitation of our study is the use of a single type of ETFT.

\section{Conclusion}

For the first time in the literature, septums were classified and ETFTs were performed prospectively. As a result, we found that ETF was significanty impaired in type 4 and 6 and was significantly improved in postop $6^{\text {th }}$ month. We recommend that the septoplasty operation be performed in patients with type 4 and 6 before middle ear surgery.

\section{Ethics}

Ethics Committee Approval: This study was approved by the Ethics Committee of Clinical Research of the Bezmialem Vakıf University Faculty of Medicine (number: 71306642-050.01.04). 
Informed Consent: Patients and healthy controls were informed about the study and informed and oral consents were taken from them.

Peer-review: Externally peer-reviewed.

Financial Disclosure: The author declared that this study received no financial support.

\section{References}

1. Şereflican M, Yurttaş V, Oral M, Yılmaz B, Dağlı M. Is Middle Ear Pressure Effected by Nasal Packings after Septoplasty? J Int Adv Otol 2015;11:63-5.

2. Akyıldız MY, Özmen ÖA, Demir UL, Kasapoğlu F, Coşkun HH, Basut Oİ, et al. Should Nasal Function be Considered Prior to Tympanoplasty? J Int Adv Otol 2018;14:53-7.

3. Salvinelli F, Casale M, Greco F, D’Ascanio L, Petitti T, Di Peco V. Nasal surgery and eustachian tube function: Effects on middle ear ventilation. Clin Otolaryngol 2005;30:409-13.

4. Van Cauwenberge P, Derycke A. The relationship between nasal and middle ear pathology. Acta Otorhinolaryngol Belg 1983;37:830-41.

5. Low WK, Willatt DJ. The relationship between middle ear pressure and deviated nasal septum. Clin Otolaryngol Allied Sci 1993;18:30810.

6. Maier W, Krebs A. Is surgery of the inner nose indicated before tympanoplasty? Effects of nasal obstruction and reconstruction on the eustachian tube. Laryngorhinootologie 1998;77:682-8.

7. Eyigor H, Osma U, Yilmaz MD, Aygener N, Buyruk A. The effect of operation success on middle ear ventilation in patients with nasal septal deviation. Kulak Burun Bogaz Ihtis Derg 2013;23:26-31.

8. Baumann I, Baumann H. A new classification of septal deviations. Rhinology 2007;45:220-3.
9. Zhen HT, Wang CF, Cui YH, Gao QX, Ge X. A new method to evaluate the eustachian tube function. Lin Chuang Er Bi Yan Hou Ke Za Zhi 2000;14:160.

10. Schilder AG, Bhutta MF, Butler CC, Holy C, Levine LH, Kvaerner $\mathrm{KJ}$, et al. Eustachian tube dysfunction: consensus statement on definition, types, clinical presentation and diagnosis. Clin Otolaryngol 2015;40:407-11.

11. Poe DS, Abou-Halawa A, Abdel-Razek O. Analysis of the dysfunctional Eustachian tube by video endoscopy. Otol Neurotol 2001;22:590-5.

12. Akyildiz MY, Özmen ÖA, Demir UL, Kasapoğlu F, Coşkun HH, Basut OI, et al. Impact of Septoplasty on Eustachian Tube Functions. J Craniofac Surg 2017;28:1929-32.

13. Buchman CA, Doyle WJ, Swarts JD, Bluestone CD. Effect of nasal obstruction on Eustachian tube function and middle ear pressure. Acta Otolaryngol 1999;119:351-5.

14. Filipovic' SA, Janosevic' L, Andric' V, Ugrinović A. Clinical evaluation of eustachian tube transience and function in patients with different types of increased nasal resistance. Vojnosanit Pregl 2009;66:353-7.

15. Deron P, Clement PA, Derde MP. Septal surgery and tubal function: early and late results. Rhinology 1995;33:7-9.

16. Tan M, Kalcioglu MT, Akarcay M, Toplu Y, Karaca S. Does Nasal Septal Deviation Affect the Success of Tympanoplasty Surgery? West Indian Med J 2015;64:393-6.

17. Eren SB, Tugrul S, Dogan R, Ozucer B, Ozturan O. Objective and subjective evaluation of operation success in patients with nasal septal deviationbased on septum type. Am J Rhinol Allergy 2014;28:e158-62.

18. Harju T, Kivekäs I, Numminen J, Rautiainen M. Eustachian Tube Dysfunction-Related Symptoms in Chronic Nasal Obstruction Caused by Inferior Turbinate Enlargement. Ann Otol Rhinol Laryngol 2017;126:798-803. 